\title{
Evaluation of Service Quality of Commercial Fitness Club Based on the QUESC Model
}

\author{
He Ying*
}

Hunan International Economics University, Changsha Hunan, 410000

\begin{abstract}
With the continuous development of social economy and standard of living, people are placing more and more emphasize on the health problem. Moreover, the idea that health can not be brought is filtering into people's minds, which influences people's life style, making people's interests to the health issue. This provides a stage to the health club which is operated for profits. Varieties of fitness clubs develop providing the physical and psychological services for people. Meanwhile, the service quality of commercial fitness club is the primary reference factor in which people choose the fitness club. Therefore, this paper uses the QUESC model to analyze the service quality of commercial fitness clubs in Changsha. Combining the analysis of means (ANOM) and analysis of variance (ANOVA), the paper points out the problems of commercial fitness clubs in Changsha and puts forward a scheme to correct them, which means a lot to the individuals and enterprises.
\end{abstract}

Keywords: Fitness club, improvement strategy, QUESC model, service quality.

\section{THEORY OF SERVICE QUALITY OF COMMER- CIAL FITNESS CLUB}

\subsection{Research of Service Quality}

Different scholars have different views of the definition of service. According to the view of marketing guru Kolter (1980), service is a activity or benefit, conveyed from one to another, it is invisible, accepting the full service won't produce the transfer of ownership, and service must not be produced on entity [1]. Yong (2000) made a analysis of service and its characteristics, summarizing three characteristics: service is an action; other factors such as material resources and environment play an important role in the process of produce of service; service is necessary to solve problem [2]. As for service quality, different people made different definition in different areas. Reeves \& Bednar (1994) believed that service quality is consumers' perception on service [3]. Service quality is divided into technical quality and function quality by Gronroos (1981), the former one is the measurable indicator when consumers accept service, the latter is the measurable indicator of service attitude when service is delivered ${ }^{[4]}$. Service quality of commercial fitness club is varieties of services (including: personnel service, equipment provided) provided for consumers and meets the consumers' needs.

\subsection{Research on Service Quality Evaluation of Fitness Club [5]}

Based on the characteristics of service quality of fitness club, some scholars measured the service quality using the multi-service quality measure tool. Some scholars ameliorated the SERVQUAL model to measure the service quality of fitness club. However, Kim (1995) constructed QUESC model based on the former model, decreasing to 11 dimensions and 33 projects from the initial 12 dimensions and 42 projects [6]. Therefore, scholars did different improvement and researched on the basis of QUESC, such as Yong and Danna (on the basis, the model has been further developed, and a multi-stage model of quality of service was put forward). In the paper, QUESC model is used to research the situation of service quality of commercial fitness club in Changsha and do the empirical analysis.

\section{RESEARCH SUBJECTS AND METHODS}

\subsection{Research Subjects}

This paper chooses 8 commercial fitness clubs which profit in good condition. The fitness clubs cover an area of at least $2000 \mathrm{~m} 2$, and they have got great body-building apparatuses. The paper gets the data through the quiz from the members of the fitness clubs in Changsha. After the selection, all the information of the valid questionnaires are adopted, and analyzed by the software SPSS21.0. The study distributes 400 questionnaires, gets 378 questionnaires back, and the qualified is 303 . All the information about the quiz are shown in Table 2-1.

\subsection{Research Methods}

\section{(1) QUSEC Model}

This paper selects 11 dimensions and 33 projects of the QUESC model, including comfortable temperature, extensive consultation, good lighting facilities. The model is to provide the valid services and requirement for consumers which evaluates the service quality of fitness clubs.

(2) Questionnaire 
Table 2-1. Sample distribution.

\begin{tabular}{|c|c|c|c|}
\hline Name & Operating Item & Address & Building Area \\
\hline World Hotels Royal Fitness Club & Fitness, Dance, Yoga, Swim & $\begin{array}{c}\text { Intersection between Xianjia New Village Road and } \\
\text { Venus Road in Yuelu District }\end{array}$ & $4000 \mathrm{~m}^{2}$ \\
\hline Xingsha Ginsberg Fitness Club & $\begin{array}{l}\text { Body Mechanics, } \\
\text { Yoga }\end{array}$ & $\begin{array}{l}\text { 3rd Floor, Building A, Xingsha Kaiyuan Road Busi- } \\
\text { ness Park }\end{array}$ & $3000 \mathrm{~m}^{2}$ \\
\hline Libo Inter Fitness Club & $\begin{array}{l}\text { Body Mechanics, } \\
\text { Sauna, Golf }\end{array}$ & Huansheng Century Xincheng in Yuelu District & $2500 \mathrm{~m}^{2}$ \\
\hline Sapphire Stadium & Dance, Yoga, Swim & Wangcheng County & $12000 \mathrm{~m}^{2}$ \\
\hline $\begin{array}{l}\text { Changsha Haidongqing } \\
\text { Fitness Club }\end{array}$ & Body Mechanics, Aerobics, Dance & $\begin{array}{c}\text { 3rd floor, unit one, } \\
\text { Oriental Ginza, } \\
\text { Yuanda Road, } \\
\text { Furong District }\end{array}$ & $2500 \mathrm{~m}^{2}$ \\
\hline Kangqi Fitness Club in Jinyuan & $\begin{array}{c}\text { Fitness, Yoga, } \\
\text { Ping-pang }\end{array}$ & $\begin{array}{c}\text { 4th floor, } \\
\text { Kaifu-Xiang River Century Golden Resources Mall }\end{array}$ & $2000 \mathrm{~m}^{2}$ \\
\hline Xingsha Direct Fitness Club & $\begin{array}{l}\text { Yoga, Sauna, } \\
\text { Ping-pang, Tennis, } \\
\text { Boxing }\end{array}$ & $\begin{array}{c}\text { 4th floor, } \\
\text { New Changhai Plaza, Intersection between Xingsha } \\
\text { Bangcha Road and Xiangyang Road }\end{array}$ & $4500 \mathrm{~m}^{2}$ \\
\hline Vitality Sport Fitness Club & Badminton & $\begin{array}{l}233 \text { Factory, } \\
\text { Zuojiatang, } \\
\text { Yuhua District }\end{array}$ & $2000 \mathrm{~m}^{2}$ \\
\hline
\end{tabular}

The quiz is for members of 8 commercial fitness clubs of Changsha, and conducts research according to the dimensions and projects of QUESC model. The research screens and neatens the evaluating indicators, according to the characteristics of the Changsha fitness clubs and consumers, eliminating five indicators, to obtain 40 items. The survey questionnaire using Likert scale is divided into two steps. The expected value of every entry is judged by membership, represented by $E$, the value of actual experience of the same item is judged, represented by A. Therefore, the calculation of the service quality is obtained, i.e., $\mathrm{Q}=\mathrm{A}-\mathrm{E}$, and is analyzing by K-means.

\section{RESEARCH RESULTS AND ANALYSIS}

\subsection{Situation and Characteristics of Members of Fitness Clubs}

The research chooses 8 commercial fitness clubs as samples, mainly investigates gender, age, education, occupation and monthly income. The valid questionnaire data is analyzed by SPSS19.0that is shown in Table 3-1 to 3-5.

Table 3-1. The gender distribution of the sample.

\begin{tabular}{|c|c|c|}
\hline Gender & Frequency & Rate of Recurrence \\
\hline \hline Male & 175 & $57.8 \%$ \\
\hline Female & 128 & $42.2 \%$ \\
\hline Total & 303 & $100 \%$ \\
\hline
\end{tabular}

Table 3-2. The age distribution of the sample.

\begin{tabular}{|c|c|c|}
\hline Age & Frequency & Rate of Recurrence \\
\hline \hline Under 20 & 31 & $10.2 \%$ \\
\hline $20-30$ & 106 & $35.0 \%$ \\
\hline $30-40$ & 92 & $30.4 \%$ \\
\hline $40-50$ & 49 & $16.2 \%$ \\
\hline Above 50 & 25 & $8.2 \%$ \\
\hline Total & 303 & $100 \%$ \\
\hline
\end{tabular}

Table 3-3. The education distribution of the sample.

\begin{tabular}{|c|c|c|}
\hline Education & Frequency & Rate of Recurrence \\
\hline \hline $\begin{array}{c}\text { High schools (including } \\
\text { technical secondary } \\
\text { school)or under high school }\end{array}$ & 57 & $18.8 \%$ \\
\hline College & 97 & $32.0 \%$ \\
\hline Undergraduate & 106 & $35.0 \%$ \\
\hline Postgraduate & 43 & $14.2 \%$ \\
\hline Total & 303 & $100 \%$ \\
\hline
\end{tabular}


Table 3-4. The occupation distribution of the sample.

\begin{tabular}{|c|c|c|}
\hline Occupation & Frequency & Rate of Recurrence \\
\hline \hline Student & 51 & $16.8 \%$ \\
\hline Institution Staff & 101 & $33.3 \%$ \\
\hline Civil Servant & 88 & $29.1 \%$ \\
\hline Workers & 63 & $20.8 \%$ \\
\hline Total & 303 & $100 \%$ \\
\hline
\end{tabular}

Table 3-5. The monthly income distribution of the sample.

\begin{tabular}{|c|c|c|}
\hline Monthly Income & Frequency & Rate of Recurrence \\
\hline \hline Under 2000 & 58 & $19.1 \%$ \\
\hline $2000-4000$ & 107 & $35.4 \%$ \\
\hline $4000-8000$ & 90 & $29.7 \%$ \\
\hline Above 8000 & 48 & $15.8 \%$ \\
\hline Total & 303 & $100 \%$ \\
\hline
\end{tabular}

In the analysis, it can be concluded that, both males and females go to the fitness clubs, males do the exercise for relieving stress, most females who are not satisfied with their figure do the exercise for shaping in good figure. The members of fitness clubs are mostly between 20 and 40, accounting for $65 \%$, who have their own fixed income and pursuit of high quality life. Most members have high educational qualifications better than junior college, accounting for $67 \%$, that is why they can realize the importance of strengthening the body and join the fitness clubs to get relieved. Occupation and monthly income distribution is more balanced; distribu- tion characte- ristic is in line with reality, ensuring that this survey is real and scientific.

\subsection{Statistical Analysis Based on QUESC Model}

According to the management of commercial fitness clubs and characteristics of consumers, the dimensions and projects of QUESC model are neatened and eliminated, eventually 40 projects are saved, the mean variance analysis of statistical data is shown in Table 3-6:

This paper adopts QUESC model, after excluding the individual dimensions, 11 dimensions are left. Each dimension has different items, environment has 7 items, attitude of club staff 5 items, Chance of Social Interaction 4 items, availability of information 4 items, offer of health plan 3 items, care for consumer 4 items, price 4 items, fundamental rights of consumer 3 items, apprehension of consumer 4 items, convenience 2 items. Set dimension is $X_{i}(i=1,2, \ldots 11)$, service quality value is $Y_{i}(i=1,2 \ldots 11)$, so the expectancy value of commercial fitness club is $\mathrm{E}_{\mathrm{i}}=\hat{\mathrm{a}}_{0}+\hat{\mathrm{a}}_{1}{ }{ }_{\mathrm{i} 1}+\ldots \ldots+\mathrm{a}_{\mathrm{p}}{ }{ }_{\text {ip }}+\varepsilon_{\mathrm{i}}$, $(i=1,2, \ldots 11, p=1,2, \ldots)$. The actual feelings value of consumer is $\mathrm{E}_{\mathrm{i}}=\hat{\mathrm{a}}_{0}+\hat{\mathrm{a}}_{1} ?_{\mathrm{i} 1}+\ldots . .+\hat{\mathrm{a}}_{\mathrm{p}} ?_{\text {ip }}+\varepsilon_{\mathrm{i}}, \quad(\mathrm{i}=1,2, \ldots 11$, $p=1,2, \ldots)$, therefore $Q_{i}=A_{i}-E_{i}, p$ represents the number of items under each dimension, $\beta_{p}$ represents the weight of different items, $A_{i}$ represents the actual feeling value. Based on the data analysis above, it can be concluded that the characteristics of service quality of the commercial fitness club are:

(1) On the whole, consumers are not satisfied with the service quality of commercial fitness clubs so much, that is to say, overall the service quality is bad. The average difference between the esthesia of service quality by consumer and the expectancy is -0.2490 , among 40 items, just few items' service quality is greater than 0 , which means that there exists a gap between the expected service of consumer and the actual service of fitness clubs.

Table 3-6. Mean variance analysis of statistics data.

\begin{tabular}{|c|c|c|c|c|c|}
\hline & Expected Value E & Actual Value A & Average & Standard Deviation & Grobach's Alpha Coefficient \\
\hline \hline Environment & 0.2569 & 0.0915 & -0.1654 & 1.1585 & 0.8077 \\
\hline Attitude of Club Staff & 0.4479 & 0.1123 & -0.3356 & 1.2956 & 0.8544 \\
\hline Reliability of Club Staff & 0.6755 & 0.1032 & -0.5723 & 1.2300 & 0.8233 \\
\hline Chance of Social Interaction & 0.3377 & 0.1365 & -0.2012 & 1.2655 & 0.8012 \\
\hline Availability of Information & 0.7011 & 0.2300 & -0.4711 & 1.2344 & 0.7546 \\
\hline Offer of Health Plan & 0.3310 & 0.2206 & -0.1104 & 1.1854 & 0.8155 \\
\hline Care for Consumer & 0.4570 & 0.1368 & -0.3202 & 1.2611 & 0.955 \\
\hline Price & 0.8831 & 0.2301 & -0.653 & 1.2233 & 0.698 \\
\hline Fundamental Rights of & 0.1350 & 0.1021 & 0.0329 & 1.2702 & 0.7422 \\
\hline Consumer & 0.7967 & 0.2356 & -0.5611 & 1.2356 & 0.785 \\
\hline Apprehension of Consumer & 0.11568 & 0.1463 & 0.0307 & 1.1755 & 0.6774 \\
\hline Convenience & & & & 0.935 \\
\hline
\end{tabular}


(2) In all the dimensions, the dimension whose average is greater than 0, are only two items- fundamental rights of consumer and convenience, this means consumers are just satisfied with these two items, as for others are not. Specifically:

1. The Changsha fitness clubs members are extremely sensitive to the price

The survey shows that consumers' perception of service quality for price minus the expectancy is -0.653 , the value is low, which indicates that Changsha consumers are not satisfied with the price of clubs

2. Most clubs ignore the study of consumers' psychology

Consumers choose any commercial fitness club is through the process of collection of information, choice judgment, decision-making and consumer evaluation process. So, it is vital to seize the psychology and preference of consumers for fitness clubs. Fitness clubs belong to service industry, the vicissitude of fitness clubs depends on whether the consumers' psychology is seized or the consumers' demands are met. However, Changsha fitness industry is under development as well as the economy, most fitness clubs ignore the psychological feelings of consumers.

3. Fitness coaches lack professional training; the overall quality needs to be improved.

In nowdays, there is a increasing competition in fitness industry, outdoors sports can not simply meet people' demands, people begin to crave more fitness knowledge and guidance. Nevertheless, most fitness clubs are not equipped with adequate professional coaches, fitness coaches do not get a high recognition of consumers, and the expectation results of consumers can not be met.

\section{Sole marketing model, less marketing channel}

Propaganda is everywhere whether in products or services, advertising is the most common mean of promotion, there is no exception, even fitness club. Through advertising, fitness clubs can expand the club image and attract more consumers. However, in the process of survey, only two clubs adopt the mean of advertising, others are not, just for cost savings.

\section{CONCLUSION AND ADVICE}

Through the analysis above, the service quality of Changsha commercial fitness clubs needs to be improved. Therefore, the counter-plan and advice are put forward to the above problem.

(1) Improve and strengthen the service quality standard, forming a certain system

By the survey of Changsha commercial fitness clubs, the local consumers' demand for physical fitness are generally mastered, besides, the collection of market information helps analyze and evaluate the actual feelings and expectancy of service provided by commercial fitness clubs. Therefore, there is necessary to develop the service quality standards in line with Changsha fact. In the process of developing the standards, the standards should be quantifiable and complete, ranging over all the aspects of commercial fitness clubs, such as facility, security, and service quality. In each stage, the controlling should be paid attention to.

(2) Strengthen the training of club staff; improve the overall quality of staff

Through the survey, consumers are not satisfied with the profession service of clubs coaches so much. With the improvement of people's living standards, the demand of fitness professional knowledge and guidance is more and more growing. Therefore, it is necessary to strengthen the training of clubs staff and improve the overall quality. Through the regular training, the staff can be possessed of abundant profession knowledge and improve their service level. Therefore, the gap between the expectancy and the actual feelings of consumers is narrowed, and the customer satisfaction is improved.

(3) Strengthen fitness club internal management, lower costs, form a certain economies of scale

According to the statistics data, consumers' are most dissatisfied with the price of commercial fitness clubs. Price influences the consumers greatly. It can be seen that, the internal management of fitness clubs is not standardized, uncoordinated, a lot of cross work occurs, which lead to the inefficient work increasing the costs. Fitness clubs in Changsha is still in development, the scale has not been formed, which results in the high costs, low earnings. Therefore, strengthening the internal management, forming a certain system could lower the price and attract more consumers.

(4) Focus on the psychology of consumers and forwardly understand consumers' demands, provide the appropriate service

This paper researches the factors which influence the consumers whether go to the fitness clubs or not, the factors are gender, age, monthly income, position. It can be seen that different consumers have different psychology and have different demands on fitness. Therefore, strengthening the research of consumers' psychology and preference can maximize the satisfaction of consumers and improve the profits of fitness clubs.

\section{CONFLICT OF INTEREST}

The authors confirm that this article content has no conflict of interest.

\section{ACKNOWLEDGEMENTS}

Declared none.

\section{REFERENCES}

[1] W.J. Kotler, "Marketing management," Prentice Hall. International Inc, vol. 5, 2000

[2] J.K. Yong, "A multidimensional and hierarchical model of service quality in the participant sport industry," Unpublished doctoral dissertation, The Ohio State University, 2000.

[3] L. Wang, "Application of measurement of service quality," Zte Technology Journal, vol. 4, pp. 25-28, 2003.

[4] C. Gronroos, "Strategic management and marketing in the service sector (Report no . 83-104) . Cambrige," MA: Marketing Science Institute, 1983. 
[5] L. Wang, and J. Xu, "Estimates analysis of service quality of commercial fitness club," Guizhou Sports Science and Technology, no. 2, pp. 22-26, 2005.
[6] L. Li, "Application of service quality of multilevel models in fitness club," Journal of Guangzhou Sports University, vol. 25, no. 6 , pp. 26-29, 2005.

Received: September 16, 2014

Revised: December 23, 2014

Accepted: December 31, 2014

(C) He Ying; Licensee Bentham Open.

This is an open access article licensed under the terms of the Creative Commons Attribution Non-Commercial License (http://creativecommons.org/licenses/by-nc/3.0/) which permits unrestricted, non-commercial use, distribution and reproduction in any medium, provided the work is properly cited. 